\title{
AGRIBISNIS PERBENIHAN KEDELAI BERKELANJUTAN (BERBASIS PROGRAM) DI KECAMATAN PANCATENGAH KABUPATEN TASIKMALAYA
}

\section{AGRIBUSINESS OF SUSTAINABLE SOYBEAN SEEDS (PROGRAM BASED) IN PANCATENGAH DISTRICT, TASIKMALAYA REGENCY}

\author{
Abid Ubaidillah*1, Trisna Insan Noor ${ }^{2}$, Meddy Rachmadi ${ }^{3}$ \\ ${ }^{1}$ Mahasiswa Pascasarjana Universitas Padjadjaran \\ ${ }^{2.3}$ Fakultas Pertanian, Universitas Padjadjaran \\ Jl. Raya Bandung-Sumedang KM. 21 Jatinangor, Jawa Barat 45363 \\ *E-mail: ubaidillahabid@gmail.com \\ (Diterima 29-10-2019; Disetujui 29-11-2019)
}

\begin{abstract}
ABSTRAK
Penggunaan benih berkualitas di Indonesia untuk komoditas kedelai baru sekitar 3\%, permasalahan mengenai benih bermutu bagi petani adalah tidak tersedia pada saat dibutuhkan. Kebijakan pemerintah untuk memacu penggunaan benih bermutu di tingkat petani adalah melalui bantuan langsung benih unggul (BLBU), dan pembentukan desa mandiri benih. Maka dilakukanlah perbaikan teknik budidaya maupun dalam tatanan lembaga agar terbentuk suatu sistem penyediaan benih yang berwawasan agribisnis dan berkelanjutan. Oleh karena itu, penelitian ini bertujuan untuk menganalisis aspek agribisnis perbenihan kedelai berkelanjutan di Kabupaten Tasikmalaya dilihat dari lima dimensi keberlanjutan yakni dimensi ekonomi, dimensi sosial, dimensi lingkungan, dimensi teknologi, dan dimensi kelembagaan. Analisis yang digunakan yaitu deskriptif kuantitatif dengan jumlah responden sebanyak 192 orang anggota petani desa mandiri benih, menggunakan teknik sampel cluster random sampling. Hasil penelitian menunjukkan bahwa kinerja agribisnis perbenihan kedelai berkelanjutan berbasis program berkinerja cukup, yang berarti masih diperlukan peningkatan pada setiap dimensi sehingga dapat memperoleh kinerja maksimal.
\end{abstract}

Kata kunci: benih, kedelai, dimensi, kinerja, berkelanjutan

\begin{abstract}
The use of quality seeds in Indonesia for new soybean commodities is around 3\%, the problem of quality seeds for farmers is not available when needed. Government policies to encourage the use of quality seeds at the farm level are through direct assistance of superior seeds (BLBU), and the establishment of seed independent villages. Then carried out improvements in cultivation techniques and in the institutional setting to form a seed supply system that is agribusiness and sustainable. Therefore, this study aims to analyze the agribusiness aspects of sustainable soybean seedling in Tasikmalaya Regency viewed from the five dimensions of sustainability namely the economic dimension, social dimension, environmental dimension, technological dimension, and institutional dimension. The analysis used is quantitative descriptive with 192 respondents consisting of independent seed farmers, using cluster random sampling technique. The results of the study showed that the performance of sustainable soybean seed-based agribusiness programs performed well enough, which meant that improvements were still needed in each dimension so as to obtain maximum performance.
\end{abstract}

Keywords: seeds, soybean, dimension, performance, sustainable 


\section{PENDAHULUAN}

Salah satu target sukses pembangunan pertanian adalah mencapai swasembada lima bahan pangan pokok yang salah satunya adalah kedelai pada tahun 2017. (Balitkabi, 2015). Produksi kedelai nasional saat ini baru mencapai 807 ribu ton (BPS 2014), sedangkan kebutuhan telah mencapai 2,3 juta ton, terdapat kekurangan 1,5 juta ton. Sementara untuk kebutuhan benih kedelai nasional kelas benih sebar 64.000 ton dan baru mampu dipenuhi sekitar 25.000 ton (BPS, 2014). Oleh karena itu, upaya peningkatan produksi kedelai nasional merupakan suatu keharusan. Penggunaan benih berkualitas adalah salah satu upaya peningkatan produksi kedelai. Penggunaan benih varietas unggul bersertifikat diyakini dapat memberikan kontribusi yang nyata dalam peningkatan produktivitas tanaman pangan (Dirjen Tanaman Pangan, 2015).

Menurut Badan Litbang Pertanian (2007), penggunaan benih berkualitas di Indonesia untuk komoditas kedelai baru sekitar 3\%, artinya petani kedelai masih banyak menggunakan benih yang tidak bersertifikat. Pada tahun 2008, penggunaan benih kedelai bersertifikat di tingkat petani hanya $2 \%$ (Suastika \& Kariada 2012). Lebih lanjut Suastika \&
Kariada (2012), mengungkapkan permasalahan mengenai benih bermutu bagi petani adalah tidak tersedia pada saat dibutuhkan. Adakalanya rantai distribusi benih dari pusat produksi sampai ke petani terlalu panjang, sehingga kualitas benih sudah menurun. Tantangan dalam penyediaan benih bermutu adalah ketersediaan benih di sentra produksi sesuai dengan kebutuhan setempat.

Kebijakan pemerintah untuk memacu penggunaan benih bermutu di tingkat petani adalah melalui bantuan langsung benih unggul (BLBU) dan pengembangan unit pengelolaan benih sumber di tingkat Balai Pengkajian Teknologi Pertanian (BPTP). Kebijakan BLBU tersebut belum mencapai sasaran secara optimal, karena dalam implementasinya belum terbentuk sistem perbenihan yang efektif dan efisien (Idaryani, 2011).

Upaya untuk mendukung pengembangan benih bermutu di Jawa Barat, diperlukan berbagai cara, baik yang bersifat teknik budidaya maupun dalam tatanan lembaga agar terbentuk suatu sistem penyediaan benih yang berwawasan agribisnis dan berkelanjutan. Petani diharapkan memiliki akses yang lebih luas dalam memperoleh varietas bermutu untuk kepentingan usahataninya 
dengan harga terjangkau, tepat waktu, dan dalam jumlah yang cukup (Muhammad et al. 2010 dalam Idaryani 2011). Salah satu daerah pengembangan sentra produksi kedelai di Jawa Barat adalah Kabupaten Tasikmalaya. Dilihat dari produksinya setiap tahun berdasarkan data BPS terus meningkat hingga menyentuh angka produksi sebesar 7.938 ton pertahunnya, yang berarti terdapat perluasan areal tanam setiap tahunnya dimana pada tahun 2010 jumlah produksi hanya mencapai 1.800 ton. (BPS, 2017).

Menurut kerangka segitiga konsep, suatu kegiatan pembangunan (termasuk pertanian dan agribisnis) dinyatakan berkelanjutan, jika kegiatan tersebut secara ekonomis, ekologis dan sosial bersifat berkelanjutan (Dahuri, 1998 dalam Rivai dan Anugrah, 2011). Berkelanjutan secara ekonomis berarti suatu kegiatan pembangunan harus dapat membuahkan pertumbuhan ekonomi, pemeliharaan kapital (capital maintenance) dan penggunaan sumber daya serta investasi secara efisien. Berkelanjutan secara ekologis mengandung arti bahwa kegiatan tersebut harus dapat mempertahankan integritas ekosistem, memelihara daya dukung lingkungan dan konservasi sumber daya alam termasuk keanekaragaman hayati (biodiversity). Sementara itu berkelanjutan secara sosial, mensyaratkan bahwa suatu kegiatan pembangunan hendaknya dapat menciptakan pemerataan hasil-hasil pembangunan, mobilitas sosial, kohesi sosial dan pengembangan kelembagaan (Rivai dan Anugrah, 2011).

Saat ini Kabupaten Tasikmalaya terutama Kecamatan Pancatengah merupakan salah satu daerah percontohan program Desa Mandiri Benih, program ini merupakan upaya pemerintah dalam meningkatkan produksi benih kedelai. Diharapkan dengan berjalannya program ini semata-mata tidak hanya untuk program jangka pendek melainkan program jangka panjang yang nantinya dapat memenuhi kebutuhan benih di tingkat Kabupaten, Provinsi, bahkan Nasional. Oleh karena itu, penelitian ini bertujuan untuk menganalisis aspek agribisnis perbenihan kedelai berkelanjutan di Kabupaten Tasikmalaya dilihat dari lima dimensi keberlanjutan yakni dimensi ekonomi, dimensi sosial, dimensi lingkungan, dimensi teknologi, dan dimensi kelembagaan. 


\section{METODE PENELITIAN}

\section{Lokasi dan Waktu}

Penelitian ini dilaksanakan di Kecamatan Pancatengah, Kabupaten Tasikmalaya Provinsi Jawa Barat. Pemilihan lokasi penelitian berdasarkan percontohan Desa Mandiri Benih dan produksi kedelai tertinggi. Waktu penelitian dilaksanakan pada bulan MaretMei tahun 2019.

\section{Jenis Penelitian}

Penelitian ini menggunakan mix methods. Penelitian kombinasi dipilih karena di dalamnya terdapat dua jenis penelitian, yakni kualitatif dan kuantitatif. Jenis kualitatif digunakan untuk memperoleh hasil validasi dan implementasi produk. Sedangkan kuantitatif digunakan untuk memahami proses validasi dan implementasi. Penelitian ini menggunakan metode survei.

\section{Variabel Penelitian}

Variabel yang diukur yaitu kinerja agribisnis perbenihan kedelai yang terdiri dari dimensi ekonomi, dimensi sosial, dimensi lingkungan, dimensi teknologi dan dimensi kelembagaan. Setiap variabel penelitian diukur menggunakan kuesioner berskala ordinal yang memenuhi pernyataan-pernyataan tipe skala likert. Menurut Sugiyono (2013), Skala likert adalah skala yang digunakan untuk mengukur sikap, pendapat, dan persepsi sesorang atau sekelompok orang tentang fenomena sosial. Guna melihat gambaran dari setiap indikator, digunakan kriteria garis kontinum, yang membagi tanggapan responden menjadi 5 kategori dengan mengubah skor kinerja menjadi presentase: sangat baik (81-100), baik (6180), cukup (41-60), kurang (21-40), dan sangat kurang (1-20).

\section{Teknik Penarikan Sampel}

Pada penelitian ini teknik sampling yang digunakan di daerah penelitian adalah Cluster Random Sampling yaitu bilamana populasi terdiri dari kelompokkelompok individu atau cluster, Total populasi berjumlah 370 orang. Selanjutnya penentuan sampel menggunkan rumus slovin dengan tingkat presisi 5\% dari populasi tersebut diperoleh sampel 192 sampel yang terdiri dari dua desa yakni Desa Cibuniasih 84 sampel, dan Desa Margaluyu 108 sampel.

\section{Teknik Pengumpulan Data}

Data primer dikumpulkan dengan teknik wawancara langsung kepada responden menggunakan alat bantu 
kuisioner, untuk mengkonfirmasi hasil wawancara responden dilakukan in depth interview yakni wawancara secara mendalam kepada ketua kelompok tani dan lembga terkait seperti Badan Penyuluh Pertanian Kecamatan (BPPK). Data sekunder diperoleh dari instansi terkait dan Badan Pusat Statistika (BPS). Rancangan analisis data yang digunakan dalam penelitian ini adalah deskriptif eksploratif kuantitatif.

\section{Rancangan Analisis Data}

Rancangan analisis data yang digunakan dalam penelitian ini adalah deskriptif eksploratif.

\section{HASIL DAN PEMBAHASAN}

Kinerja keberlanjutan agribisnis perbenihan kedelai ini dijelaskan secara deskriptif berdasarkan hasil analisis lapang yang dibagi dalam 5 dimensi kinerja yakni, dimensi ekonomi, dimensi sosial, dimensi lingkungan, dimensi teknologi, dan dimensi kelembagaan.

Deskripsi ini dapat memberikan gambaran kondisi keberlanjutan agribisnis perbenihan kedelai di Kecamatan Pancatengah. Sehingga dapat memberikan masukan terhadap pembuatan model agribisnis perbenihan kedelai berkelanjutan (berbasis komunitas) di
Kecamatan Pancatengah Kabupaten Tasikmalaya.

\section{A. Dimensi Ekonomi}

Dimensi ekonomi merupakan aspek utama dalam usahatani, dimana keberlangsungan usahatani dapat dikatakan layak ketika usahatani yang dijalankan memiliki $\mathrm{R} / \mathrm{C}$ ratio lebih dari 1 dan harga jual memuaskan petani. Berikut ini merupakan tabel kinerja dimensi ekonomi.

Berdasarkan data pada Tabel 1 dapat disimpulkan jika indeks rata-rata variabel dimensi ekonomi $65 \%$ atau berkinerja cukup. Hal ini dikarenakan $\mathrm{R} / \mathrm{C}$ ratio dari atau kelayakan usahatani benih kedelai berada diatas 1 atau dinyatakan layak untuk dijalankan. Baiknya R/C ratio ini dipengaruhi dengan ketersedian input produksi yang cukup mudah diperoleh dan harganya yang relataif terjaungkau. Selain itu, faktor dari adanya program bantuan desa mandiri benih memberikan dampak positif terhadap pendapatan petani. Selanjutnya nilai indeks rata-rata harga jual benih kedelai terhitung rendah dengan hanya memperoleh nilai 58,8\% berkinerja cukup, penentuan harga jual ditentukan berdasarkan Break Even Point (BEP) usahatani. Hal ini diperkuat oleh hasil penelitian Swastika dan Baladina (2016) 
Jika petani merasa puas ketika benih yang diproduksinya dapat terjual tanpa berfikir margin keuntungan.

Pada kenyataannya berdasarkan pengamatan lapang harga jual benih di tingkat petani sangatlah rendah berkisar Rp 6.500 hingga Rp 8.000. Padahal harga benih yang dijual resmi oleh penangkar atau pedagang serta dinas pertanian berkisar antara $\mathrm{Rp} 12.000$ hingga $\mathrm{Rp}$ 15.000, bahkan ada yang menjual dengan harga diatas itu. Ini berarti ada permasalahan berkenaan dengan penetapan harga jual karena petani mendapat margin keuntungan terendah namun dengan resiko dan beban yang paling besar.

Tabel 1. Kinerja Dimensi Ekonomi Agribisnis Perbenihan Kedelai Berkelanjutan di Kabupaten Tasikmalaya

\begin{tabular}{lrr}
\hline \multicolumn{1}{c}{ Dimensi Ekonomi } & Jumlah & Presentase \\
\hline 1. R/C Ratio & 1 & 0,05 \\
$<0,5$ & 42 & 21,87 \\
$0,51-0,95$ & 0 & 0 \\
$=1$ & 145 & 75,52 \\
$1,01-2$ & 4 & 2,08 \\
$>2$ & $\mathbf{1 9 2}$ & $\mathbf{1 0 0}$ \\
Total & & 0 \\
\hline 2. Harga Jual & 0 & 5,20 \\
Rp 3.680-Rp 5.258 & 10 & 94,80 \\
Rp 5.259-Rp 6.837 & 182 & 0 \\
Rp 6.838-Rp 8.416 & 0 & 0 \\
Rp 8.417-Rp 9.995 & 0 & $\mathbf{1 0 0}$ \\
Rp 9.996-Rp 11.574 & $\mathbf{1 9 2}$ & Kinerja \\
Total & Indeks Rata-rata (\%) \\
\hline & 71,2 & Baik \\
\hline R/C Ratio & 58,8 & Cukup \\
Harga Jual & $\mathbf{6 5 , 0}$ & Baik \\
Nilai Rata-rata & & \\
\hline
\end{tabular}

\section{B. Dimensi Sosial}

Dimensi sosial merupakan salah satu dimensi yang digunakan untuk mengukur kinerja sosial petani dalam usahatani kedelai. Menurut Priyono dalam Fredi (2018) Dimensi sosial adalah orientasi kerakyatan, berkaitan dengan kebutuhan akan kesejahteraan sosial yang dicerminkan oleh kehidupan sosial yang harmonis (termasuk tercegahnya konflik sosial), preservasi keragaman budaya dan modal sosio-kebudayaan, termasuk perlindungan terhadap suku minoritas. Dimensi sosial terdiri dari regenerasi petani, pemberdayaan petani, dan dukungan sosial budaya masyarakat. Berikut ini merupakan kinerja dari setiap variabel yang terdapat pada dimensi sosial. 
MIMBAR AGRIBISNIS

Jurnal Pemikiran Masyarakat Ilmiah Berwawasan Agribisnis. Januari 2020. 6(1): 141-154

Tabel 2. Kinerja Dimensi Sosial Agribisnis Perbenihan Kedelai Berkelanjutan di Kabupaten Tasikmalaya

\begin{tabular}{lcc}
\hline \multicolumn{1}{c}{ Dimensi Sosial } & $\begin{array}{c}\text { Indeks Rata- } \\
\text { rata (\%) }\end{array}$ & Kinerja \\
\hline 1. Regenerasi Petani & 40,4 & Kurang \\
Ada amanat (permintaan) dan tuntutan keluarga & 38,2 & Kurang \\
Tuntutan melajutkan usaha agribisnis keluarga & 43,2 & Kurang \\
Di didik/dimagangkan oleh keluarga & 42,4 & Kurang \\
Anak akan melanjutkan usahatani Bapak/Ibu sebagai Petani & 40,2 & Kurang \\
Generasi muda keluarga tani berminat di sektor pertanian kedelai & 43,6 & Cukup \\
Generasi muda terjun langsung sebagai pelaku usahatani kedelai & $\mathbf{4 1 , 4}$ & Cukup \\
Total & & \\
\hline 2. Pemberdayaan Petani & 78,2 & Baik \\
Perlu bekerjasama dengan petani lain dalam kegiatan usaha & 78,2 & Baik \\
Perlu mencari informasi baru tentang usahatani kedelai & 77,6 & Baik \\
Gotong royong dalam penyediaan sarana dan prasarana untuk mendukung & & \\
kegiatan usahatani & 77,6 & Baik \\
Mengikuti program pelatihan yang mendukung kegiatan usahatani & 79,2 & Baik \\
Menjadi anggota aktif dalam jejaring/kelompok/komunitas/organisasi & $\mathbf{7 8 , 2}$ & Baik \\
Total & & \\
\hline 3. Dukungan Sosial Budaya Masyarakat & 56,8 & Cukup \\
Mengikuti penyuluhan/pelatihan pangan karena didorong warga masyarakat & 60,8 & Cukup \\
Usahatani kedelai dikelola oleh kelompok/komunitas & 60,6 & Cukup \\
Mengusahakan kedelai lokal sudah menjadi budaya setempat & $\mathbf{5 9 , 4}$ & Cukup \\
Total & $\mathbf{5 9 , 6}$ & Cukup \\
\hline Indeks Rata-rata Dimensi Sosial (\%) &
\end{tabular}

Berdasarkan Tabel 2, variabel pemberdayaan petani memiliki kinerja paling baik diantara dua variabel lainnya dengan indeks rata-rata $78,2 \%$ berkinerja baik. Penelitian di lapangan menunjukkan jika petani merasa terbantu dengan adanya program pemberdayaan, kegiatan pemberdayaan tersebut berupa pendampingan dari mulai pelatihan budidaya kedelai mulai dari awal penanaman hingga pasca panen. Hal ini sejalan dengan Suradisastra (2008), menyatakan keberhasilan suatu program pemberdayaan merupakan resultan interaksi elemen-elemen pemberdayaan dengan strategi pemberdayaan yang diterapkan. Baiknya kinerja pemberdayaan petani di Kecamatan Pancatengah ditunjukkan dengan berjalannya program desa mandiri benih. Sedangkan variabel regenerasi petani mendapat kinerja terburuk dengan nilai indeks rata-rata 41,4\% berkinerja kurang. Ini ditunjukkan dengan kondisi di lapangan jika petani kedelai mayoritas berumur diatas 40 tahun, dan sedikit sekali petani yang melakukan usahatani kedelai dengan umur dibawah 30 tahun. Dalam penelitian Prayoga (2018), motif yang melatarbelakangi pemuda desa untuk menjadi petani sangatlah majemuk, yang paling dominan karena memang latar 
belakang mereka dari kecil sudah akrab dengan dunia pertanian dan didasari dengan kecintaan terhadap dunia pertanian. Lalu, berkaca pada teori yang dikemukakan oleh Frederick Herzberg tentang motif seseorang ketika bekerja maka motif pemuda Desa Bulukerto dalam bekerja menjadi petani dapat dilihat dari faktor pemuas kerja (job satisfiers) dan faktor ketidakpuasan kerja (job dissatisfiers). Terakhir aspek ekonomi memegang peranan penting yang mendasari pemuda desa untuk bertani karena melihat penerimaan usahatani dirasa mampu menjamin kehidupan mereka bukan karena kondisi sosial budaya. Namun, selain karena aspek ekonomi yang mendasari keputusan mereka, aspek kecintaan terhadap sektor pertanian karena sosialisasi sejak dini yang mereka dapatkan.

\section{Dimensi Lingkungan}

Dimensi Lingkungan merupakan salah satu dimensi yang didalamnya terdapat variabel-variabel berkenaan dengan keseimbangan lingkungan. Variabel dimensi lingkungan terdiri dari indikator kesadaran lingkungan, bagaimana petani sadar akan pentingnya menjaga lingkungan pertanian, adaptasi dan mitigasi iklim merupakan suatu upaya adaptasi petani terdapat perubahan iklim, penggunaan input organik yang digunakan petani pada saat usahatani, dan terakhir upaya petani dalam menjaga kesuburan lahan dan pencegahan yang dilakukan terhadap serangan hama.

Berdasarkan data yang terdapat pada Tabel 3 dimensi lingkungan terlihat jika indikator menjaga kesuburan lahan dan mengurangi resiko serangan hama memiliki indeks rata-rata tertinggi dengan nilai 78,4 atau berkinerja baik. Sebagaimana ditunjukkan pada saat penelitian jika petani sudah memahami pentingnya rotani tani tanaman guna menjaga keseimbangan tumbuh tanaman kedelai. Hal ini sejalan dengan penelitian Sari et al., (2012), bila pengelolaan lingkungan tumbuh tidak dilakukan dengan baik, potensi daya hasil biji yang tinggi dari benih unggul tersebut tidak dapat tercapai. Sedangkan penggunaan indikator penggunaan input organik mendapat indeks rata-rata terendah dengan nilai $41,6 \%$ atau berkinerja cukup memuaskan. Rendahnya penggunaan input organik petani kedelai di pancatengah terlihat dengan masih dominannya penggunaan pupuk anorganik yang dirasa petani lebih cepat dalam membantu pertumbuhan kedelai dibandingkan input organik. Sehingga dapat disimpulkan jika penggunaan input 
organik petani masih sangat rendah, padahal berdasarkan penelitian Dosis tersebut lebih besar dibandingkan hasil penelitian Taufiq et al. (2003), yang menunjukkan bahwa pemberian pupuk kandang 2,5 t/ha pada lahan masam di
Tulang Bawang mampu meningkatkan hasil kedelai sebesar $8,3 \%$ dari 1,2 t/ha menjadi 1,3 t/ha, dan meningkatkan hasil sebesar $11,1 \%$ dari $1,8 \mathrm{t} /$ ha menjadi 2,0 t/ha di lahan masam Lampung Tengah.

Tabel 3. Kinerja Dimensi Lingkungan Agribisnis Perbenihan Kedelai Berkelanjutan di Kabupaten Tasikmalaya

\begin{tabular}{|c|c|c|}
\hline Dimensi Lingkungan & $\begin{array}{l}\text { Indeks Rata- } \\
\quad \text { rata }(\%)\end{array}$ & Kinerja \\
\hline \multicolumn{3}{|l|}{ 1. Kesadaran Lingkungan } \\
\hline $\begin{array}{l}\text { Unsur lingkungan merupakan faktor yang harus dipertimbangkan dalam } \\
\text { usahatani kedelai }\end{array}$ & 60,6 & Cukup \\
\hline $\begin{array}{l}\text { Usahatani kedelai memiliki manfaat untuk memperbaiki dan menjaga } \\
\text { kesuburan lahan }\end{array}$ & 59,6 & Cukup \\
\hline $\begin{array}{l}\text { Memanfaatkan limbah usahatani untuk dimanfaatkan sebagai bahan pupuk } \\
\text { organiK }\end{array}$ & 58,8 & Cukup \\
\hline Tidak menggunakan pestisida jika belum ada serangan hama penyakit & 38,6 & Kurang \\
\hline Total & 54,4 & Cukup \\
\hline \multicolumn{3}{|l|}{ 2. Adaptasi dan Mitigasi Perubahan Iklim } \\
\hline Penyesuaian jadwal tanam untuk mengantisipasi perubahan iklim & 77,8 & Baik \\
\hline Pembuatan embung sebagai cadangan kebutuhan air & 38,8 & Kurang \\
\hline Mengusahakan kedelai karena sesuai daya dukung lahan & 78,4 & Baik \\
\hline Penyediaan pompa air (pinjam atau beli) untuk mengatasi kekeringan & 40,2 & Kurang \\
\hline $\begin{array}{l}\text { Perawatan dan perbaikan saluran air untuk mengantisipasi kelebihan/ } \\
\text { kekurangan air }\end{array}$ & 39,8 & Kurang \\
\hline Total & $\mathbf{5 5 , 0}$ & Cukup \\
\hline \multicolumn{3}{|l|}{ 3. Penggunaan Input Organik } \\
\hline $\begin{array}{l}\text { Aktif memproduksi pestisida/pupuk/benih/bahan baku sendiri berbasis } \\
\text { organik }\end{array}$ & 31 & Kurang \\
\hline Kebutuhan pupuk kandang selalu dari ternak sendiri & 60,4 & Cukup \\
\hline Aktif meningkatkan penggunaan pupuk/pestisida hayati & 33,6 & Kurang \\
\hline Total & 41,6 & Cukup \\
\hline \multicolumn{3}{|l|}{ 4. Menjaga Kesuburan Lahan dan Mengurangi Resiko Serangan Hama } \\
\hline Penanaman kedelai sebagai rotasi tanaman menambah kesuburan tanah & 77,6 & Baik \\
\hline Penanaman kedelai sebagai rotasi tanaman memudahkan pengolahan lahan & 77,6 & Baik \\
\hline Penanaman kedelai sebagai rotasi tanaman mengurangi gulma jahat & 77,8 & Baik \\
\hline $\begin{array}{l}\text { Penanaman kedelai sebagai rotasi tanaman mengurangi resiko serangan hama } \\
\text { pada tanaman kedelai }\end{array}$ & 80,6 & Baik \\
\hline Total & $\mathbf{7 8 , 4}$ & Baik \\
\hline Indeks rata-rata Dimensi Lingkungan (\%) & 57,3 & Cukup \\
\hline
\end{tabular}

\section{Dimensi Teknologi}

Dimensi teknologi merupakan dimensi yang didalamnya terdapat penggunaan teknologi dalam proses usahatani kedelai di Kecamatan
Pancatengah. Pada dimensi ini terdapat dua variabel yakni variabel produktivitas dan variabel inovasi teknologi. Berikut ini merupakan tabel kinerja dimensi teknologi. 
Tabel 4. Kinerja Dimensi Teknologi Agribisnis Perbenihan Kedelai Berkelanjutan di Kabupaten Tasikmalaya

\begin{tabular}{|c|c|c|}
\hline Dimensi Teknologi & $\begin{array}{l}\text { Indeks Rata- } \\
\text { rata }(\%)\end{array}$ & Kinerja \\
\hline \multicolumn{3}{|l|}{ 1. Produktivitas } \\
\hline Produktivitas semakin tinggi & 78,8 & Baik \\
\hline Varietas baru meningkatkan produktivitas & 77,0 & Baik \\
\hline Teknologi baru meningkatkan produktivitas & 76,8 & Baik \\
\hline Benih berlabel meningkatkan produksi dan produktivitas & 78,2 & Baik \\
\hline Pengolahan tanah lengkap meningkatkan produksi dan produktivitas & 78,4 & Baik \\
\hline Pemberian pupuk berimbang meningkatkan produksi dan produktivitas & 78,6 & Baik \\
\hline $\begin{array}{l}\text { Pengendalian hama dan penyakit terpadu dapat mempertahankan kehulangan } \\
\text { hasil }\end{array}$ & 77,0 & Baik \\
\hline Total & $\mathbf{7 7 , 8}$ & Baik \\
\hline \multicolumn{3}{|l|}{ 2. Inovasi Teknologi } \\
\hline Teknologi baru budidaya kedelai tersedia dan mudah diakses & 59,4 & Cukup \\
\hline Selalu mengikuti perkembangan teknologi budidaya kedelai & 59,6 & Cukup \\
\hline Melakukan uji coba dari teknologi budidaya kedelai terbaru & 58,8 & Cukup \\
\hline Mencoba menerapkan teknologi budidaya kedelai terbaru & 58,6 & Cukup \\
\hline Total & $\mathbf{5 9 , 2}$ & Cukup \\
\hline Nilai Rata-rata Dimensi Teknologi & 68,5 & Baik \\
\hline
\end{tabular}

Berdasarkan data pada Tabel 4, nilai indeks rata-rata tertinggi terdapat pada variabel produktivitas sebesar $77,8 \%$ dengan kinerja baik. Jika mengacu pada kondisi di lapangan produktivitas meningkat hanya di lahan sawah saja, sedangkan untuk penanaman di lahan kering masih jauh dibawah 80\%. Baik dan buruknya produktivitas dikarenakan ketidaksesuaian jenis benih yang digunakan. Menurut Zakaria (2010), produktivitas kedelai dipengaruhi oleh jenis tanah, kualitas benih, varietas. pengelolaan tanaman, takaran pupuk, pengendalian hama penyakit, waktu tanam dan teknologi budidaya yang dianjurkan, yang brarti ketika produktivitas meningkat ada perbaikan pada setiap input dan perlakuan lainnya. Sedangkan variabel inovasi hanya berkinerja cukup dengan nilai 59,2\%. Inovasi teknologi dalam budidaya kedelai di Kecamatan Pancatengah cenderung tidak terjadi perubahan, karena petani hingga penelitian dilakukan masih menggunakan alat sederhana namun tetep dapat menunjang proses perbenihan. Akan tetapi, aspek efektif dan efisien dari proses budidaya tersebut masih belum maksimal. Hal ini sejalan dengan penelitian Zakaria (2010), bahwa tingkat penerapan teknologi budidaya kedelai masih dibawah teknologi yang dianjurkan pemerintah. Di lain pihak, pelaksanaan kegiatan usahatani kedelai di tingkat petani adalah layak diusahakan karena nilai imbangan pendapatan dan biaya $(\mathrm{R} / \mathrm{C})$ adalah lebih dari satu. Uraian lengkap dari setiap variabel akan dijelaskan pada sub bab berikutnya. 


\section{E. Dimensi Kelembagaan}

Dimensi kelembagaan dalam aspek keberlanjutan perbenihan kedelai memiliki peran yang berhubungan dengan kelompok tani dan aturan adat. Aspek kelembagaan ini diukur guna melihat pengaruh peran kelembagaan terhadap keberlangsungan usahatani perbenihan kedelai berkelanjutan. Berikut ini merupakan data kinerja lengkap dimensi kelembagaan.

Tabel 5. Kinerja Dimensi Kelembagaan Agribisnis Perbenihan Kedelai Berkelanjutan di Kabupaten Tasikmalaya

\begin{tabular}{lcc}
\hline \multicolumn{1}{c}{ Dimensi Kelembagaan } & $\begin{array}{c}\text { Indeks Rata- } \\
\text { rata (\%) }\end{array}$ & Kinerja \\
\hline 1. Kelompok Tani & 95,8 & Sangat Baik \\
Adanya kelompok tani membantu distribusi perbenihan & 96,8 & $\begin{array}{c}\text { Sangat Baik } \\
\text { Adanya kelompok tani mempermudah pemasaran }\end{array}$ \\
Kelompok tani menjamin ketersediaan bantuan & 90,6 & Sangat Baik \\
Aktif dalam kegiatan kelompok tani & 96,8 & Sangat Baik \\
Kegiatan dalam kelompok tani menambah wawasan usahatani kedelai & 88,8 & Sangat Baik \\
Total & $\mathbf{9 3 , 8}$ & Sangat Baik \\
\hline 2. Aturan Adat & & \\
Patuh terhadap adat istiadat yang berlaku di daerah & 78,6 & Baik \\
Adanya aturan adat dapat mempererat kekeluargaan antar sesama petani & 79,0 & Baik \\
Aturan adat mempermudah dalam budidaya kedelai & 76,2 & Baik \\
Aturan adat menentukan kesesuaian waktu tanam dan panen & 53,4 & Cukup \\
Total & $\mathbf{7 1 , 8}$ & Baik \\
\hline Nilai Rata-rata Dimensi Kelembagaan & $\mathbf{8 2 , 8}$ & Sangat Baik \\
\hline
\end{tabular}

Berdasarkan data pada Tabel 5, variabel kelompok tani dapat dikatakan hampir mendapatkan nilai dengan sempurna dengan nilai $93,8 \%$ atau berkinerja sangat baik. Hal ini sesuai dengan kondisi di lapangan jika kelompok tani memiliki peranan yang cukup penting, selain karena dapat mengakomodir semua petani yang tergabung dalam kelompok tani kedelai, kelompok tani juga dapat menjaga keberlangsungan program desa mandiri benih yang ditandai dengan tersalurkannya input dengan baik dan output atau hasil produksi kedelai dapat terjual. Sebagaimana hasil penelitian Nuryanti dan Swastika (2011), menyatakan umumnya setiap bantuan diserahkan melalui kelompok tani pun dengan petani yang ingin mendapatkan teknologi baru harus menjadi anggota kelompok dan gapoktan, dengan demikian peran kelompok tani tidak hanya sebagai agen penyaluran melainkan sebagai agen penerapan teknologi. Pada dimensi kelembagaan dimaksudkan petani untuk menjadi kelompok tani sebagai komunitas penangkar benih, sehingga para petani dapat saling membantu dalam ketersediaan benih, tidak hanya menjadi 
pelaku budidayanya saja akan tetapi menjadi pelaku pemasaran. Dengan demikian petani dapat memperoleh keuntungan dengan margin yang cukup besar ketimbang hanya menjadi pelaku budidaya benih saja. Sedangkan aturan adat mendapat indeks rata-rata $71,8 \%$ setara dengan kinerja baik. Di lapangan tidak terlihat banyak aturan adat yang menentukan keberlangsungan usahatani akan tetapi, adanya aturan dapat menjaga hubungan kekeluargaan sesama petani kedelai dan kebiasaan menanam kedelai pada peiode waktu tertentu ditentukan oleh kesepakatan bersama dalam aturan adat tersebut. Menurut Suhartini (2010), baiknya kinerja dari adat adalah tanda baiknya perpaduan adat dengan teknologi dan lingkungan, sehingga dapat membantu jalannya usahatani.

\section{F. Kinerja Dimensi Agribisnis Perbenihan Kedelai Berkelanjutan Berbasis Program}

Jika pada sub bab sebelumnya telah dijelaskan kinerja dari setiap dimensi perbenihan kedelai berkalnjutan, berikut ini merupakan data sajian keseluruhan dari kinerja perbenihan kedelai berkelanjutan berbasis program di Kecamatan Pancatengah, Kabupaten Tasikmalaya.

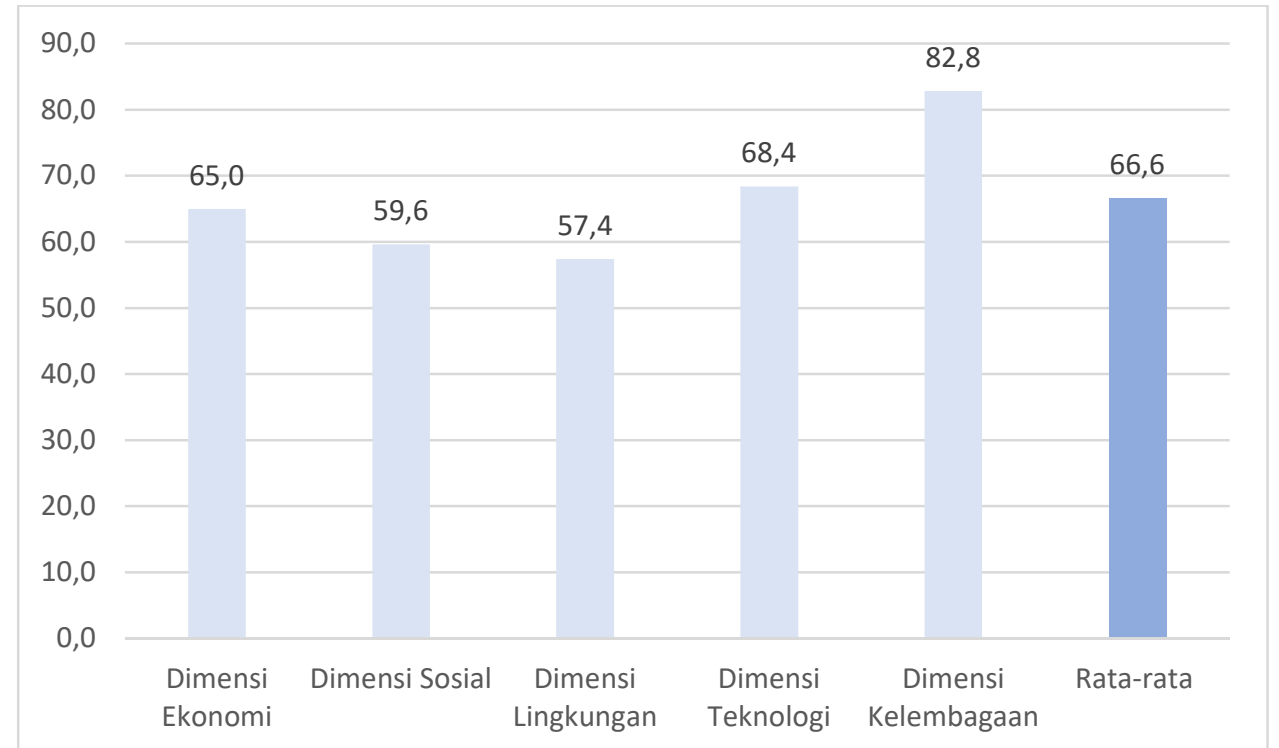

Gambar 1. Grafik Chart Kinerja Agribisnis Perbenihan Berkelanjutan Berbasis Program

Berdasarkan gambar diatas dapat disimpulkan jika keseluruhan kinerja agribisnis perbenihan kedelai berkelanjutan berbasis termasuk dalam kategori kinerja baik, ini ditunjukkan dengan nilai indeks rata-rata $66,6 \%$. Akan tetepi, ada sekitar 34\% kinerja yang dapat ditingkatkan guna memperoleh kinerja 
maksimal pada setiap dimensinya. Kinerja dimensi kelembagaan merupakan kinerja tertinggi dengan nilai $82,8 \%$ atau berkinerja sangat baik. Berdasarkan kondisi di lapangan petani sangat terbantu dengan adanya lembaga seperti kelompok tani baik dalam penyediaan input produksi maupun dalam pemasaran terhadap benih kedelai yang dihasilkan. Hasil ini berbanding terbalik dengan penelitian Tedjaningsih, Suyudi, dan Nuryaman (2018), kinerja kelembagaan menunjukkan bahwa kelembagaan agribisnis mendong masih perlu ditingkatkan lagi agar mampu menghadapi tantangan persaingan dengan penguatan kemandirian petani melalui peningkatan fungsi kelompok tani sebagai

\section{KESIMPULAN DAN SARAN}

Secara umum kinerja agribisnis perbenihan kedelai berkelanjutan berbasis program di Kecamatan Pancatengah Kabupaten Tasikmalaya memiliki kinerja cukup. Hal ini berarti kinerja dari agribisnis perbenihan belum mencapai titik maksimal atau masih bisa dilakukan peningkatan kinerja pada setiap dimensinya terutama pada dimensi lingkungan dan dimensi sosial. unit produksi dan pengadaan sarana produksi. Sedangkan dimensi lingkungan berkinerja terendah dengan nilai $57,4 \%$ atau berkinerja cukup. Belum maksimalnya kinerja dari dimensi lingkungan adalah masih dominannya penggunaan bahan anorganik dalam proses usahatani kedelai. Hasil ini diperkuat oleh penelitian Widiriani et al. (2008), hasil analisis Leverage menunjukkan bahwa lima atribut dimensi ekologi yang salah satunya penggunaan input organik berpengaruh terhadap keberlanjutan. Sehingga rendahnya aspek ekologi akan berpengaruh terhadap agribisnis perbenihan kedelai berkelanjutan.

\section{UCAPAN TERIMA KASIH}

Terimakasih peneliti ucapkan kepada Badan Penyuluh Pertanian Kecamatan Pancatengah dan Dinas Pertanian Kabupaten Tasikmalaya, serta rekan civitas akademika Pascasarjana Universitas Padjadjaran yang telah membersamai dalam penelitian.

\section{DAFTAR PUSTAKA}

Balitkabi. (2015). Prinsip-prinsip Produksi Benih Kedelai. Pusat Penelitian dan Pengembangan Tanaman Pangan. Balai Penelitian dan Pengembangan Pertanian. IAARD Press. 2015. 
Badan Litbang Pertanian. (2007). Pedoman Umum Produksi Benih Sumber Kedelai. Departemen Pertanian.

Badan Pusat Statistik. (2014). Jawa Barat Dalam Angka. Badan Pusat Statistik.

Direktorat Jenderal Tanaman Pangan. 2015. Pedoman Teknis Pemberdayaan Penangkar Benih Tahun Anggaran 2015. Jakarta.

Idaryani. (2011). Kajian Sistim Penyediaan Benih Kedelai Bermutu di Sulawesi Selatan. Sekolah Pascasarjana Institut Pertanian Bogor 2011.

Nuryanti \& Swastika. (2011). Peran Kelompok Tani Dalam penerapan Teknologi Pertanian. Forum Penelitian Agroekonomi, Volume 29 No. 2

Prayoga K. 2018. Pilihan Hidup Bertani Pemuda Desa Di Tengah Laju Urbanisasi Pada Masyarakat Desa Bulukerto Kecamatan Bumiaji Kota Batu. Tesis. Sekolah Pascasarjana Universitas Gadjah Mada Yogyakarta.

Rivai, R.S, \& Anugrah I.S. (2011). Konsep dan Implementasi Pembangunan Pertanian Berkelanjutan di Indonesia. Pusat Sosial Ekonomi dan Kebijakan Pertanian.

Sari P.M, Aimon H, Syofyan E. (2012). Analisis Faktor-faktor Yang Mempengaruhi Produksi, Konsumsi, Dan Impor Kedelai Di Indonesia. Jurnal Kajian Ekonomi, Juli, Vol III, No.5 2012.

Suastika, I.B. \& I.K. Kariada. (2012). Kajian sistem penyediaan benih unggul bermutu kedelaI dalam mendukung program strategis peningkatan produksi kedelai di wilayah Bali. Pros. Seminar Kedaulatan Pangan dan Energi Universitas Trunojoyo Madura.
Sugiyono, (2013). Metode Penelitian Kuantitatif-Kualitatif dan $R \& D$, Bandung: Alfabeta.

Suhartini. (2010). Kajian Kearifan Lokal Masyarakat Dalam Pengelolaan Sumberdaya Alam dan Lingkungan. Jurusan Pendidikan Biologi FMIPA Universitas Negeri Yogyakarta.

Suradisastra K. (2008). Strategi Pemberdayaan Kelembagaan Petani. Pusat Analisis Sosial Ekonomi dan Kebijakan Pertanian. Forum Penerilitian Agro Ekonomi, Vol 28 No.2, Desember 2008.

Swastika E.V, \& Baladina N. (2016). Analisis Struktur, Perilaku, dan Penampilan Pasar Output dan Pasar Input Kedelai Lokal di Desa Mlorah. Prosiding. Seminar Nasional Pembangunan Pertanian. Fakultas Pertanian Universitas Brawijaya Malang. 2016.

Taufiq, A., H. Kuntyastuti, Sudaryono, A.G. Manshuri, Suryantini, Tri Wardani dan Cipto P. (2003). Perbaikan dan peningkatan efisiensi teknik produksi kedelai di lahan kering masam. Laporan Teknik Balitkabi Tahun 2003.

Tedjaningsih T, Suyudi, Nuryaman H. (2018). Peran Kelembagaan Dalam Pengembangan Agribisnis Mendong. Mimbar Agribisnis. Jurnal Pemikiran Masyarakat Ilmiah Berwawasan Agribisnis. 2018. 4(2): 210-226.

Widiarini R, Sabiham S, Sutjahjo HS, Las I. 2008. Analisis Keberlanjutan Usahatani di Kawasan Rawan Erosi. Jurnal Tanah dan Iklim No. 29/2009 ISSN 1410 - 7244.

Zakaria A.K. (2010). Dampak Penerapan Teknologi Usahatani Kedelai Di Agrosistem Lahan Kering Terhadap Pendapatan Petani. Agrika, Volume 4 No.2, November 2010. 